\title{
Penerapan Person-Centered Untuk Meningkatkan Kepercayaan Diri Rendah Pada Mahasiswi STKIP
}

\author{
Nurhayati \\ 1,2,3 Universitas Aisyah Pringsewu \\ e-mail: nurhayatidian0106@gmail.com
}

\begin{abstract}
Abstrak. Self Confidance yang tinggi merupakan salah satu faktor penting untuk meraih prestasi bagi mahasiswa, dengan meraih prestasi yang tinggi mahasiswa akan merasa bangga dan bahagia. Berbeda dengan mahasiswa yang memiliki self confidance yang rendah, mereka tidak akan mencoba untuk berhasil dalam apapun karena mereka berpikir akan gagal jika mereka melakukannya. Mahasiswa menilai dirinya mudah pesimis, malas dalam mengerjakan tugas yang diberikan dosen, mengumpulkan tugas tidak tepat waktu dan tidak bisa menargetkan lulus kuliah. Tujuan dalam penelitian ini adalah untuk mengetahui gambaran kepercayaan diri rendah pada mahasiswa dan mengetahui hasil person centered untuk meningkatkan kepercayaan diri mahasiswa. Metodologi yang digunakan adalah dengan pendekatan single case experiment Pada penelitian ini desain yang digunakan adalah $A-B-A$ design, yaitu desain penelitian yang terdiri dari dua fase baseline sehingga memungkinkan untuk mengetahui hubungan sebab akibat antara variabel terikat dan variabel bebas. Pengukuran perilaku menggunakan metode pencatatan berupa interval recording dengan interval waktu 30 menit. Bahwa program intervensi ini, yang terdiri dari person centered cukup efektif dalam mengatasi kepercayaan diri rendah mahasiswa. Dengan perolehan hasil yang menunjukan adanya perubahan mean persentase percaya diri yang rendah $S$ pada tahap baseline (A1), intervensi, dan baseline (A2). Pada tahap baseline (A1), mean persentase percaya diri rendah berkisar antara 78,7\% sampai dengan $79,8 \%$. Kemudian dilakukan intervensi psikologis dalam dalam bentuk person centered. Pada tahap intervensi, mean perilaku berkisar antara $85 \%$ sampai dengan $10 \%$ artinya mengalami penurunan. Kemudian setelah intervensi dihentikan, peneliti melakukan pengulangan baseline (A2) dan diperoleh mean persentase percaya diri rendah berada pada kisaran 21,95\% hingga $4,05 \%$ dan mengalami penurunan setelah di intervensi. Dari intervensi yang dilakukan terhadap $S$ dengan person centered terlihat bahwa terdapat perubahan yang lebih baik, yaitu berkurangnya kepercayaan diri yang rendah.
\end{abstract}

Kata kunci: Percaya diri, Person centered; Mahasiswa

\section{Pendahuluan}

Mahasiswa yang menjalani kuliah dikampus ada yang merasa kurang percaya diri (lack of confidence). Ketika menghadapi permasalahan dan keadaan itu dapat menghambat proses perkuliahannya, antara lain merasa tidak nyaman bersama dosen, takut berdiskusi dengan dosen, takut untuk menemui dosen, sulit menyelesaikan tugas-tugas kuliah tepat waktu dan merasa khawatir gagal, mendapatkan nilai yang rendah maupun IPK yang kurang memuaskan. Dengan pengalaman yang negatif dari lingkungan dapat menimbulkan rasa tidak aman, tidak yakin akan kemampuannya, tidak mandiri dan pesimis dalam mengatasi permasalahan tersebut. Untuk mengatasi permasalahan tersebut dibutuhkan self confidance (rasa percaya diri), kepercayaan diri akan muncul apabila individu tidak mempunyai ketergantungan terhadap suatu hal, karena yakin dengan ada dalam dirinya dan yakin akan kemampuannya. 
Self Confidance yang tinggi merupakan salah satu faktor penting untuk meraih prestasi bagi mahasiswa, dengan meraih prestasi yang tinggi mahasiswa akan merasa bangga dan bahagia. Berbeda dengan mahasiswa yang memiliki self confidance yang rendah, mereka tidak akan mencoba untuk berhasil dalam apapun karena mereka berpikir akan gagal jika mereka melakukannya. Mahasiswa menilai dirinya mudah pesimis, malas dalam mengerjakan tugas yang diberikan dosen, mengumpulkan tugas tidak tepat waktu dan tidak bisa menargetkan lulus kuliah.

Kepercayaan diri adalah sesuatu yang tak ternilai, dengan memiliki rasa percaya diri, seseorang dapt melakukan apa pun dengan keyakinan bahwa itu akan berhasil, apabila ternyata gagal, seseorang tidak pantas putus asa tetapi tetap memiliki semangat, tetap bersikap realistis. Hal ini senada dengan pendapat Lautser (2002), kepercayaan diri adalah suatu sikap atau perasaan yakin atas kemampuan dirinya, sehingga individu dapat memilih hal-hal yang disukainya, tidak terlalu cemas dalam menlakukan tindakan-tindakannya dan bertanggung jawab atas perbuatannya. Kurang percaya diri mula-mula disebabkan oleh perasaan cemas dan tidak tenang serta perasaan-perasaan lain yang mengikutinya, seperti malas, kurang sabar, sulit, susah atau rendah diri. Dengan perasaan tersebut, individu menjadi ragu akan kemampuan dan dirinya, hal inilah yang membuat orang tidak percaya diri (Luxori, 2004). Maka dalam menjalani hidup seseorang harus selalu mengembangkan rasa kepercayaan dirinya. Krisis kepercayaan diri membawa individu ke dalam sebuah perjuangan (Nursadrina, A., \& Andriani, D. 2020).

\section{Metode}

\section{Variabel Penelitian}

Variabel penelitian adalah segala sesuatu yang dapat diukur dan dinilai, baik menggunakan alat atau menggunakan instrument yang telah ditentukan cara pengukurannya. Penelitian ini menggunakan variabel independent, yaitu variabel yang menyebabkan atau mempengaruhi faktor-faktor yang di ukur atau dipilih oleh peneliti untuk menentukan hubungan antara fenomena yang diobservasi dan diamati.

$\mathrm{X}=$ Kepercayaan Diri (variabel dependent)

$\mathrm{Y}=$ Person Centered (variabel independent)

\section{Subyek Penelitian}

Penelitian ini menggunakan satu subyek, yang disebut dengan single case. Kasus dipilih sesuai minat dan tujuan khusus yang diuraikan dalam tujuan penelitian. Teknik pemilihan subyek menggunakan teknik purposive sampling, dimana sampel diambil dengan maksud dan tujuan tertentu. Subyek dipilih sebagai sampel karena peneliti menganggap bahwa subyek memiliki informasi yang diperlukan bagi penelitian. Peneliti hanya mengambil individu yang dinilai memiliki informasi yang dibutuhkan dan bersedia membagi informasi tersebut (Kumar, 2005). Pada penelitian kasus ini menjadi subyek penelitian atau klien adalah: a) Mahasiswa perempuan yang tergolong memiliki kepercayaan diri rendah; b) Mahasiswa semester 2

\section{Instrumen Penelitian}

Penelitian ini menggunakan tipe single-case experiment, yaitu penelitian yang melihat perubahan perilaku pada subyek tunggal. Penelitian ini tidak banyak menggunakan analisa statistik. Untuk mengetahui pengaruh variabel eksperimen dilakukan melalui pengamatan secara terus-menerus 
terhadap perilaku subyek tunggal sebelum dan setelah treatmen diberikan (Shaughnessy, Zechmeister, \& Zechmeister, 2003).

Pada single-case experiment, terdapat beberapa desain penelitian yang dapat digunakan. Pada penelitian ini desain yang digunakan adalah A-B-A design, yaitu desain penelitian yang terdiri dari dua fase baseline sehingga memungkinkan untuk mengetahui hubungan sebab akibat antara variabel terikat dan variabel bebas (Sunanto, Takeuchi, \& Nakata, 2005).

Prosedur pelaksanaan A-B-A design adalah peneliti melakukan observasi secara terus menerus pada fase baseline (A1) dengan periode waktu tertentu sebelum diberikan intervensi. Setelah diperoleh data pada fase baseline (A1), selanjutnya peneliti melakukan intervensi dan selama fase intervensi (B) perilaku subyek kembali diobservasi. Kemudian pada saat intervensi dihentikan, maka akan dilakukan fase baseline yang kedua (A2), dimana peneliti kembali melakukan observasi terhadap perilaku subyek (Cozby, 2008).

\section{Metode Analisis Data}

Berdasarkan hasil analisis, menunjukkan adanya perubahan perilaku pada subjek setelah diberikan intervensi. Pada intervensi ke 2 mulai berubah, pada intervensi ke 4 mulai berubah, dan pada intervensi ke 5,6,7,8,9,10 dan 11 mulai berubah, sehingga mengalami penurunan Berarti setelah 11 kali intervensi, perilakunya mulai berubah. Perubahan perilakunya setelah intervensi, yaitu mulai mengurangi katifitas melamun dan bermain fb disaat jam kuliah dan mulai untuk berinteraksi dengan teman-temannya, serta mulai mau terbuka tentang pribadinya, walaupun belum maksimal.

\section{Hasil Penelitian}

Pada saat ini Taraf kecerdasan S dalam kategori di bawah rata-rata / Low average yaitu potensi kecerdasan (FULL IQ =84, OIQ: 73), hal ini menandakan $S$ belum dapat mengoptimalkan kemampuan intelektualnya. (VIQ = $85 \mathrm{PIQ}=85$ Skala Weschler). Ia memiliki kemampuan penalaran verbal yang sama dengan performance (low average), Artinya $\mathrm{S}$ kurang mudah memahami informasi yang berhubungan dengan bahasa atau kata-kata. Untuk menangkap materi yang bersifat nonverbal seperti berupa gambar atau symbol ia agak lambat. Cara berfikirnya cenderung kaku dalam melihat permasalahan sehingga ia kurang dapat memandang permasalahan dari berbagai sudut pandang. S kurang mengusai permasalahan berhitung yang membutuhkan imajinasi atau bersifat abstrak. Pelajaran hitungan seperti matematika dirasakan cukup sulit untuk dikuasai. Wawasan pengetahuan yang dimilikinya juga masih kurang, hal tersebut berkaitan dengan kemampuan daya ingat yang dimilikinya. Pelajaran yang membutuhkan daya ingat atau bersifat hafalan sangat dikuasai olehnya. Kecekatan visual motor serta kemampuan menganalisa cukup baik. Sert kemampuan mensintesiskan bentuk pun cukup baik, artinya ia dapat merespon cukup baik terhadap suatu kegagalan.

$\mathrm{S}$ adalah individu yang introvert, ia senang menyembunyikan masalahnya, sehingga ia termasuk individu yang sensitive. Secara intelektual ia pun memiliki hambatan dan membuat dirinya menjadi seseorang yang kurang percaya diri. Ia merasa tidak nyaman dengan keadaan lingkungannya. Karena rasa tidak percaya dirinya rendah, ia kurang diakui di lingkungannya serta merasa tergantung dengan orang lain dan secara emosioanl ia kurang matang. Peran ayah yang sangat dominan membuatnya sangat tertekan dan tidak nyaman, namun ada sosok ibunya yang selalu membantunya, walaupun itu jarang sekali ia ungkapkan ke ibunya.

Untuk menyelesaikan tugas- tugas yang dihadapi ia merasa kurang mampu, sehingga kesulitan dalam memecahkan masalah menggunakan pikirannya secara optimal. Ia jga kurang mampu untuk 
menerima pendapat orang lain dan kurang mampu untuk menyesuaikan diri dan untuk dapat bekerja dengan tertib dan teratur ia juga kurang mampu. Namun ia mau menolong orang lain jika ada yang merasa kesulitan, sehingga pemahaman terhadap orang lain cukup baik. Ia juga senang jika mendapatkan simpati dan perhatian dari orang lain. S merasa kurang dominan terhadap kelompok, merasa tertekan, merasa rendah diri dan mengalah. $\mathrm{S}$ memiliki minat pada bidang practical dengan point sebesar 32. Hasil pemeriksaan tersebut sesuai dengan minat yang dimiliki olehnya dari hasil autoanamnesa dengannya.

Setelah mengadakan penelitian, penelitian ini mendukung intervensi person centered. Disarankan S menjalankan hasil konseling yang telah diberikan pada saat intervensi dengan konsinten. Mempertahankan perilaku yang sudah baik, misalnya : berinteraksi dan mulai terbuka, sehingga mendapat wawasan yang lebih luas. Berdasarkan hasil penelitian, metode person centered dengan konseling non-direktif cukup efektif dalam mengatasi percaya diri yang rendah pada mahasiswa. Oleh karena itu, sebagai tindak lanjut, orangtua diharapkan dapat menerapkan metode tersebut di rumah, dengan asumsi jika kepercayaan diri yang rendah menurun selama berinteraksi dilingkungan, diharapkan saat di kampus perilaku sosialisasi siswa dapat lebih memunculkan perilaku yang diharapkan. Misalnya: saling menghargai pendapat dan mampu menjalin kebersamaan dan Mengembalikan kepercayaan diri, seperti melupakan kegagalannya di masa lalu dengan cara melakukan beberapa aktivitas yang positif. Sehingga mendapatkan wawasan yang lebih luas dan dapat berinteraksi dengan baik.

\section{Kesimpulan dan Saran}

Berdasarkan data-data yang diperoleh dan hasil pembahasan, maka dapat ditarik kesimpulan bahwa program intervensi ini, yang terdiri dari person centered cukup efektif dalam mengatasi kepercayaan diri rendah mahasiswa. Dengan perolehan hasil yang menunjukan adanya perubahan mean persentase percaya diri yang rendah S pada tahap baseline (A1), intervensi, dan baseline (A2). Pada tahap baseline (A1), mean persentase percaya diri rendah berkisar antara 78,7\% sampai dengan 79,8\%. Kemudian dilakukan intervensi psikologis dalam dalam bentuk person centered. Pada tahap intervensi, mean perilaku berkisar antara $85 \%$ sampai dengan $10 \%$ artinya mengalami penurunan.

Kemudian setelah intervensi dihentikan, peneliti melakukan pengulangan baseline (A2) dan diperoleh mean persentase percaya diri rendah berada pada kisaran 21,95\% hingga 4,05 \% dan mengalami penurunan setelah di intervensi. Dari intervensi yang dilakukan terhadap S dengan person centered terlihat bahwa terdapat perubahan yang lebih baik, yaitu berkurangnya kepercayaan diri yang rendah.

\section{Daftar Pustaka}

Alter, Peter J., Wyrick, Amanda.,Brown, E. Todd., \& Lingo, Amy. 2008. Improving Mathematics Problem Solving Skills for Student With Challenging Behavior. http://www.ccbd.net/sites/default/files/bebe-1703-2.pdf. Diakses pada tanggal 10 Maret 2012.

Anthony, R. 1992. Rahasia Membangun Kepercayaan Diri. (terjemahan Rita Wiryadi). Jakarta: Binarupa Aksara 
Bandura , A. (1994). Self-efficacy. In, V . S. Ramachaudran (Ed) Encyclopedia of human behavior (Vol 4, pp. 71-81). New York, NY : Academic Press Rertieved 27 November, 2005 from http:/wwww.des.esmory.edu/mfp.html

Blum, J Dorothy. 1998. The School Counselor's Book Of List. The Centered For Applied Reserch In Education

Corey, G. (2009). Theory and Practice Of Counseling And Psychotherapy. USA: Thomson Books.

Corey, Gerald. 2010. Teori dan Praktek Konseling dan Psikoterapi. Bandung: PT Refika Aditama.

Chou (2011).Sejarah Person's Centered. (Online), diakses pada tanggal 19 Oktober 2011 di http:/kupukupucantik.blogspot.com/2011/01/sejarah-terapi-person-centered.html

Centi, P. J. 1995. Mengapa Rendah Diri . Yogyakarta : Kanisius

Feist, Jess \& Gregory J, Fest. (2011). Teori kepribadian, edisi 7 buku 2. Jakarta : Salemba Humanika.

http:/kandidatkonselor.blogspot.com/2013/01/teori-dan-pendekatan-konseling-person.html

Ivey, A. E., D'Andrea, M., Ivey, M. B., \& Simek-Morgan, L. (2009). Theories Of Conseling Dan Psychotherapy. Canada: Pearson Education, Inc.

Kerlinger, F. N. 1990. Asas-Asas Penelitian Behavioral. Yogyakarta : Gajah Mada University Press.

Kumar, Ranjit. 2005. Research Methodology : A Step-By-Step Guide for Beginners. London : SAGE Publications Ltd.

Lauster, P. 1997. Test Kepribadian ( terjemahan Cecilia, G. Sumekto ). Yoyakarta.

Kanisius

McLeod. J. (2008). Pengantar Konseling, teori dan studi kasus. Jakarta: Kencana.

Mukhlis, H., Triaristina, A., Wahyudi, D. A., Kameliwati, F., \& Putri, R. H. (2020). Anxiety Confronts Practice Exam Reviewed from Optimism, Emotional Intelligence, and Social Support on Student of STIKES. Journal of Talent Development and Excellence, 12(2s), 830-842.

Nursadrina, A., \& Andriani, D. (2020). Gambaran Coping Strategies pada Mahasiswa Universitas Padjadjaran. Journal of Psychological Perspective, 2(1), 01 - $11 . \quad$ Retrieved from https://ukinstitute.org/journals/jopp/article/view/2101

Pintrich \& Schunck. (1996). Motivation in Education, Theory. Research and Application. Columbus Ohio ; Prentice Hall.

Roger, R. Carl. 2012. On Becoming a Person. Yogyakarta : Pustaka Pelajar

Santrock, John W. 1995. Life-Span Development (5th ed). Jakarta : Erlangga.

Sarwono, S. W. (2002). Berkenalan Dengan Aliran-Aliran dan Tokoh tokoh Psikologi. Jakarta: Bulan Bintang.

Sunanto, Juang, Takeuchi, Koji, \& Nakata, Hideo. 2005. Pengantar Penelitian dengan Subyek Tunggal. CRICED : University of Tsukuba.

Thawanty. (1997). Kamus bimbingan dan konseling. Yayasan Bimbingan dan Konseling Indonesia: Pamator Yusuf Luxori (2004). Percaya diri. Jakarta Timur: Khalifa 